\title{
DISPLASIA CLEIDOCRANIANA: RELATO DE CASO CLÍNICO
}

José Guilherme da CUNHA, Ana Paula PINTO, Cassiana Caldeira REICHMANN, Luciana SIGNORINI

A displasia cleidocraniana, é uma síndrome congênita rara. O fenótipo dos portadores da síndrome apresenta alterações nos ossos membranosos como a clavícula e os ossos que constituem o crânio, alguns estudos mostraram que a ossificação endocondral também é comprometida, assim representando uma desordem generalizada das estruturas esqueléticas. As alterações bucais são inúmeras como: palato arqueado, estreito e fundo, prognatismo, dentes supranumerários inclusos e dificuldades de irrupção dos dentes permanentes devido ao periodonto fibroso e falta da formação de cemento radicular. Este trabalho relata o caso clínico da paciente I. K., leucoderma, 43 anos que compareceu ao consultório particular para avaliação de "dentes crescendo embaixo da prótese". A anamnese da paciente revelou aumento do 1/3 superior da face, atresia ântero-posterior da maxila, prognatismo mandibular, diminuição da dimensão vertical de oclusão e as próteses totais superior e inferior apresentavam desgaste, falta de adaptação e mobilidade durante a mastigação. 